\title{
The challenge of diversity in rural regions: refugee reception in the German federal state of Saxony
}

\author{
BIRGIT GLORIUS ${ }^{1}$
}

\begin{abstract}
Recent inflows of asylum seekers and their internal redistribution have confronted many European countries with questions of how to integrate the newcomers without neglecting needs, fears and perceptions of the resident population. This is especially true for rural regions in East Germany, which has experienced huge internal outmigration since the political and economic transformation period following 1989-1990, but which never has been were a destination for international migrants. Based on theoretical approaches from sociology and social psychology, the paper analyses local reception conditions, attitudes and perceptions of local populations and decision makers in rural regions of the East German federal state of Saxony, following the research question of how individual and group related attitudes develop and how those are reflected and responded to by public decision makers. Findings suggest that the migration history and the political and economic development are important context factors for the understanding of local reception conditions. Lacking experiences with diversity, combined with the involuntariness of refugee allocation, provides for a hostile environment and xenophobic behaviour. On the other hand, the opportunity to experience first-hand contacts to migrants in the neighbourhood can support the acculturation process and subsequently change public attitudes towards migrants and refugees. The perception of relative deprivation, which is found specifically in vulnerable groups in the context of transformation situations, can result in destructive attitudes and can jeopardize democratic processes and puts public representatives under pressure. The paper concludes that the challenge to integrate refugees could bring forward general debates about social cohesion and might furthermore fuel processes of institutional adaptation and social innovation. In order to maintain social peace, it recommends the empowerment of local actors in rural regions to take over a leading role in local discourses, actively support civic engagement and fight the effects of destructive discourses.
\end{abstract}

Keywords: diversity, migration, refugee reception, Pegida, rural regions, East Germany

\section{Introduction and research questions}

Migration has severely changed the population structure and social fabric of many regions in Europe. Especially in recent years, many urban but also peripheral, rural regions in Europe experienced increasing population diversity due to the inflow of various groups of migrants, among them European free movers, labour migrants from third countries and refugees ${ }^{2}$. Contrary to ur- ban agglomerations, rural communities often have few experiences with diversity.

In Germany, the huge inflow of refugees since 2013 and their redistribution among federal states and counties confronted many rural municipalities with questions of integration and diversity for the first time. Dealing with those questions we can observe a new East-West divide, with the post-socialist part of Germany appearing as especially hostile, xenophobic and even dangerous for

\footnotetext{
${ }^{1}$ Technische Universität Chemnitz, Institute for European Studies, Thüringer Weg 9, 09126 Chemnitz, Germany. E-mail: birgit.glorius@phil.tu-chemnitz.de

${ }^{2}$ In this article the term "refugee" is used to characterise a person who fled his or her country. The term does not reflect the formal status of the fled person in the asylum process.
} 
foreigners. A longitudinal study on the reception culture in Germany revealed that recently almost every second East German citizen believes that immigrants are not welcome in Germany, while in West Germany, this perception is found in one third of the population (Bertelsman Foundation 2015, 16). As those differences were not found in earlier versions of the survey, it can be assumed that East and West Germany are developing in different directions concerning the willingness and ability to develop a welcoming reception environment for immigrants.

Differences regarding the openness towards immigrants can be found throughout Europe. The European Eurobarometersurvey shows differing perceptions concerning immigration in accordance to age and social status. Negative and hostile perceptions were especially frequent in older age groups and in those groups with low social status (European Commision 2015, 151). Thus, the socio-economic and age profile of regions may serve as part of an explanatory frame for the analysis of diverging reception cultures.

In Germany, regional differences are not only found in perceptions towards immigrants, but also in practices like for example criminal attacks against foreigners or refugee accommodations. Police statistics covering the year 2015 revealed a high number of criminal assaults against refugee accommodations in most East German federal states. In Saxony, with a share of 5 per cent at the total population and accommodating 6 per cent of asylum seekers, there occurred more than one tenth of all incidents against refugee accommodations in 2015 (JANSEN, F. 2016).

Several factors are currently debated as an explanation for those obvious differences. First, there are considerable differences concerning experiences with heterogeneity, which is due to the different immigration histories of the two German states. Also, the experience of political, economic and social transformation in East Germany seems to play a role. Particularly for inhabitants of rural areas in East Germany, the transfor- mation period was associated with various losses. Experiences of personal loss (such as the loss of employment and social status or loss of social networks due to outmigration of family members) mingled with the (perceived) disconnection from economic and social progress, which also included the dismantling of public infrastructure. Those processes of "peripheralisation" particularly hit the more vulnerable segments of rural populations, such as the elderly, the poorly educated and the unemployed and poor people (LAschewski, L. 2009; Leibert, T. and GoLINSKI, S. 2017).

Another argument is the persisting stance from socialist times not to be a self-determined subject, but rather a victim of state intervention. This attitude prevents a reflection on creative possibilities of the self and promotes the retreat into private life, political abstinence and a general mistrust of public institutions and political actors (HiLsBerg, S. 2015).

This paper takes off from those principal considerations in order to explore the perceptions and practices of refugee reception in a post-socialist rural part of Germany. The paper discusses explanations concerning the development of xenophobia and analyses how notions of xenophobia transfer into practice of both residents and public authorities.

Following the introduction, in section 2 the paper will elaborate explanatory approaches on integration, acculturation and xenophobia and give an overview on existing research concerning migration, integration and diversity in rural regions. Section 3 introduces the case study region in terms of economic and population development and migration history as an explanatory frame for the empirical research. Section 4 reports on the research methodology and the main findings, which are finally discussed and generalized in section 5 . The paper draws on statistical material and case studies which the author and co-workers carried out in the federal state of Saxony in the course of the years 2015 and 2016. 


\section{Migration and integration in rural regions - explanatory approaches and empirical evidence}

\section{Explanatory approaches on integration, accul- turation and xenophobia}

Dealing with the question of preparedness of local communities for the reception of international migrants, it is important to consider the two-sidedness of the integration process, affecting migrants as well as members of the host society. Historical key approaches from integration research like the race-relationscycle focus on the role of newcomers and the steps they have to take in order to become a full member of the host society (PARK, R. and Burgess, E.W. 1921; TAFT, R. 1957). Integration is seen as a multi-step process, which provides for a gradual approach to different segments of the host society until full assimilation. At the same time a gradual alienation from the society of origin occurs. More recent approaches suggest the alternative of simultaneous integration in societies of origin and arrival and the development of transnational identities (Pries, L. 1997; Welsch, W. 1999). In addition, the integration of migrants into the host society is no longer equated to assimilation, but it is rather conceptualized as equal participation, while the migrants' different characteristics and cultures are accepted by the host society. But even those approaches lack the perspective on the host society's characteristics and the designation of factors that enable, promote or hinder the integration of foreigners.

The requirements of intercultural understanding are addressed in approaches from cross-cultural psychology. In REDFIELD et al.'s acculturation approach, acculturation is described as a bundle of phenomena "which result when groups of individuals having different cultures come into continuous first-hand contact, with subsequent changes in the original culture patterns of either or both groups" (REDFIeld, R. et al. 1936, 149). Thus, basic elements of the acculturation process are contact (continuous and first-hand), reciprocal influence and change. BERRY, J.W. (2006) furthermore stresses the contextual configurations of acculturation, considering the diversity of the reception society and its acculturation strategies as well as the voluntariness of migration. Reflecting those approaches, we can hypothesize that the host society's constitution in terms of socioeconomic situation, demographic development and migration history will influence integration and acculturation processes. In addition to the experience of heterogeneity, the socio-economic situation of the specific locality must be considered in order to describe differences in the ability to integrate.

For a better understanding of the dynamics and quality of inter-group-relations, approaches from social psychology are helpful which focus on social group identity. Following TAjFel, H. and Turner, J.C. (1986), social identity is the "part of an individual's self-conception derived from the perceived membership in a relevant social group". Social identity theory predicts intergroup behaviour considering perceptions of group status differences, legitimacy and stability of those differences and the ability to move from one group to another group.

The development of negative dynamics in inter-group-relations is correlated with the endangerment of status devaluation, for example in the context of social or economic transformation processes. In those situations, social groups may react with active degradation of groups which are perceived to rank lower, or because of a perceived competition in the context of social benefit allocation. This mechanism is also referred to as relative deprivation (Pettigrew, T.F. 2001). This approach appears to be especially suitable for the analysis of intergroup relations in transformation situations. Several empirical studies show correlations between relative deprivation and the development of right wing attitudes in various European countries (Heitmeyer, W. 2010; Küpper, B. and Zick, A. 2010).

Regarding the general openness towards foreigners, the form of nationhood seems to 
play a crucial role. Especially, the "ethnic" type of national feeling was found to correlate with features of xenophobia, (HJERm, M. 1998) while the "civic" type produced a greater openness towards heterogeneous societies and furthermore correlated with a higher level of institutional legitimacy (BILliET, J. et al. 2003; Ceobanu, A.M. and Escandell, X. 2008). Several authors discuss the prevalence of the "ethnic" type of national belonging in post-socialist societies due to specific historical paths into nationhood, which might be object to challenge and change during the European integration process (Sмітн, A.D. 1991; White, G.W. 2000; HJerm, M. 2003).

\section{Empirical evidence on integration and diversity in rural regions}

Empirical research results on the effects of rural society structures and infrastructures on the integration of foreigners are scarce. In Germany, Hoffmeyer-Zlotnik, J. (2000) used the data of the German General Social Survey (ALLBUS) 1996 with a total of 3,290 interviewees to determine the influence of the settlement structure on attitudes against foreigners. His findings show that discriminatory positions are mainly influenced by education, age and existing contact with foreigners. People with high education, previous contacts to foreigners and low age displayed the least discrimination tendencies. Regarding regional differences, HoffMeyerZLOTNIK, J. (2000) showed that the discrimination of foreigners in cities is lower than in the countryside, while discriminatory attitudes were generally higher in East Germany than in the west of the country.

NADLER, R. et al. (2010) studied international migration into peripheral rural regions, focusing on the specific potential international immigration could have for the development and competitiveness of rural regions. Using empirical case study material from the West German Saar region and the East of Saxony, they focused on the attitudes and experiences of international migrants and their reflec- tions of integration and acceptance in rural settlements.

They differentiated two groups of international migrants in terms of migration motivation and lifestyle: career oriented migrants on the one hand, and family life oriented migrants on the other. The group of highly skilled and career-oriented migrants reported a strong distance between themselves and rural German neighbours; as a reason, they identified less their foreign origin than their higher education and cosmopolitanism, which divided them from their rural neighbours and sometimes led to retreat of the latter (NADLER, R. et al. 2010, 115). The group of family oriented migrants often showed more active efforts to integrate and had more everyday interactions with rural German inhabitants. They reported discriminatory experiences, particularly if they showed visible cultural differences, like wearing a headscarf. Some reported that due to the widespread rural poverty, they would rather hide their own (good) economic status for not arousing envy among the locals (ibid. 116). NadLer, R. et al. (2010) conclude that positive effects of international migration in rural areas can only occur if newly arriving migrants manage to become firmly rooted in the social community.

A recent locality study by Roos, U.M. (2016) on migration and integration of foreigners in the rural town of Merzig in the German SaarRegion compared the attitudes towards integration, xenophobia and heterogeneity among local residents with and without migration biography. Roos, U.M. (2016) revealed that the positive attitudes against foreigners correlated with the intensity of intergroup-connections in the direct neighbourhood, personal private contacts and contacts at the workplace. Generalizing from her empirical results, she concluded that intercultural contacts and neighbourly relations have a strong positive influence on integration processes in rural settlements. Furthermore, she stressed the significance of key persons (such as mayors, teachers and so forth) for the development of public attitudes, as they are strongly accepted as role models in rural societies. 
Also a number of policy oriented studies on integration practices in rural settlements confirm the results elaborated above, notably that rural settlement structures lead to a higher degree of social control; that exclusionary practices against newcomers and the perception of cultural differences are strong; and that there is a lack of ethnic networks, interculturally trained professionals or differentiated integration structures which could support integration (cp. Мiкsch, J. and Schwier, A. 2000; Schader-Stiftung 2011; Gruber, M. 2013). Furthermore, all studies stress the role of key persons for the local integratory climate. The publicly displayed personal attitude of the mayor, the teacher or the local priest towards immigration and foreigners can significantly influence the public climate and, thus, form an important basis for acceptance and integration of foreigners in local societies.

\section{The federal state of Saxony as source and destination of migration}

In the following section the paper will briefly describe the socio-demographic development of the case study region since 1989/90 in order to empirically frame the analysis of reception and integration practices and the social conflicts arising from the arrival of asylum seekers.

\section{Internal migration and demographic decline}

The federal state of Saxony already experienced population losses prior to the transformation period, but since the political revolution of 1989, the outflow increased tremendously. Between 1990 and 1993, more than 400,000 people left Saxony, which makes 8.5 per cent of its 4.7 million inhabitants. Between 1990 and 2013, the population number decreased by 15 per cent, due to emigration and declining birth numbers (4.7 million to 4.0 million) (StBA 2014). ${ }^{3}$ Emigration was

\footnotetext{
${ }^{3}$ Between 2013 and 2016, the population slightly increased from $4,046,385$ to $4,084,851$, mainly due to net migration gains of foreign population.
}

highly segregated by age, education and gender, leading to an extended peripheralisation process of geographically remote and rural regions. While mostly younger and better educated people (among them a high proportion of women) left, the remaining population represented growing proportions of elderly, unemployed and less educated people, who faced an ongoing downsizing process of public infrastructure and a stagnation of economic development (Glorius, B. 2015, 26) (Photo 1 and 2).

Those processes proceeded with high regional variation (Figure 1). Especially remote areas and de-industrializing regions experienced a population loss of up to one quarter of their population and a continuing outmigration. The age-selectivity of outmigration and the constantly low birth rates simultaneously led to a sharp increase of the average age. Notably the counties in the Erzgebirge mountains along the Czech border as well as in the district of Bautzen and in parts of the rural core of Saxony are strongly ageing. Thus, e.g. the municipality of Johanngeorgenstadt in the southern Erzgebirge lost more than half of its population between 1990 and 2013; the average age increased by 13.6 years to 51.1 years in the same time.

\section{International migrants in Saxony}

The former German Democratic Republic (GDR) had a low level of internationalization. The immigration regime mainly provided for temporary labour migration without possibilities to stay for good; also students and scientists from other socialist countries lived in the GDR, as well as small numbers of political refugees and migrants who arrived due to marriage with a GDR citizen. In 1989 a total of 190,400 foreigners (1\% of the total population) lived in the GDR, of which 93,568 were contract workers (BADE, K. and Oltmer, J. 2004, 95). For comparison, the share of foreign population in the former Federal Republic of Germany (FRG) was 8 per cent at the end of the 1980s. 


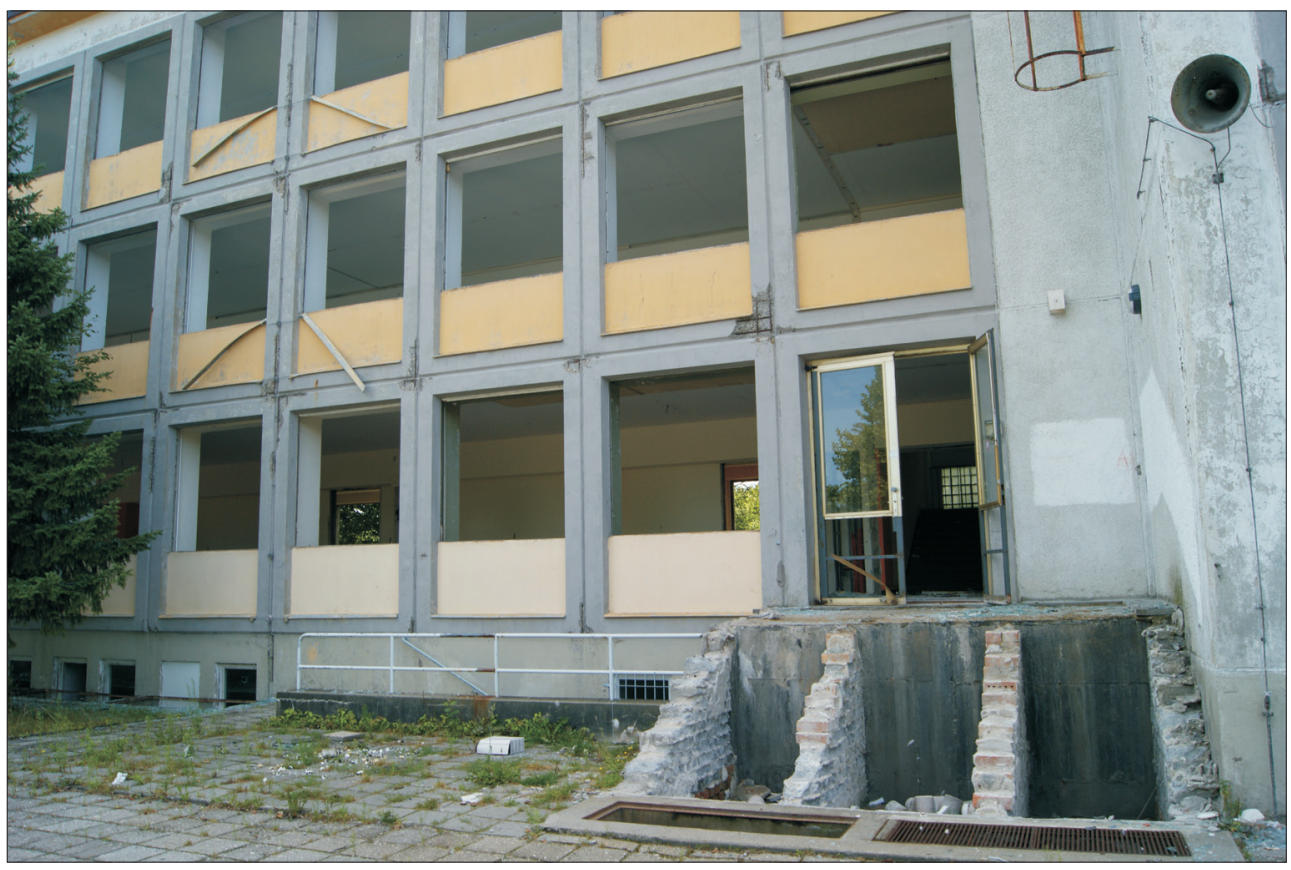

Photo 1. Abandoned school building in a small town in Saxony. Photo by Glorius, B.

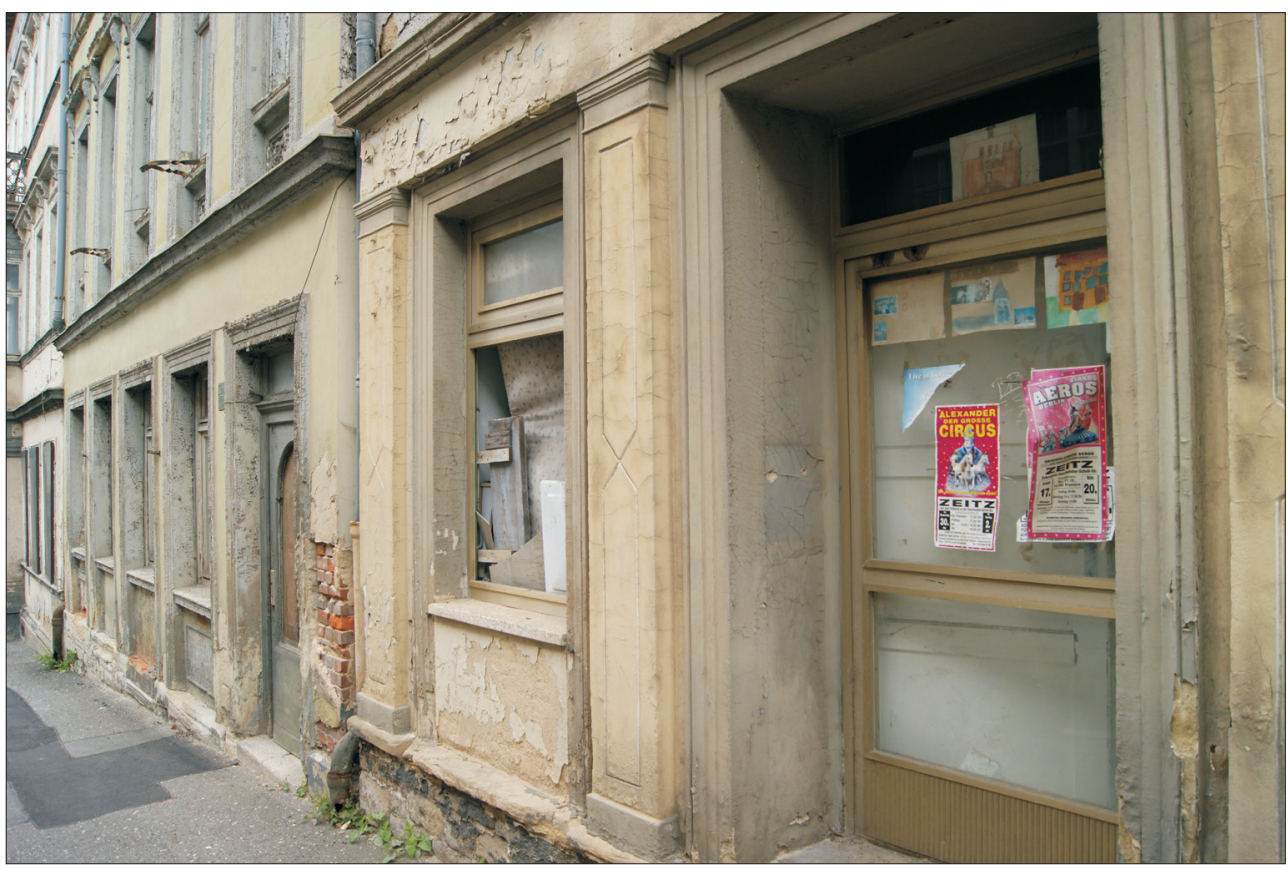

Photo 2. Empty shops in a provincial town center, Saxony. Photo by GLorius, B. 


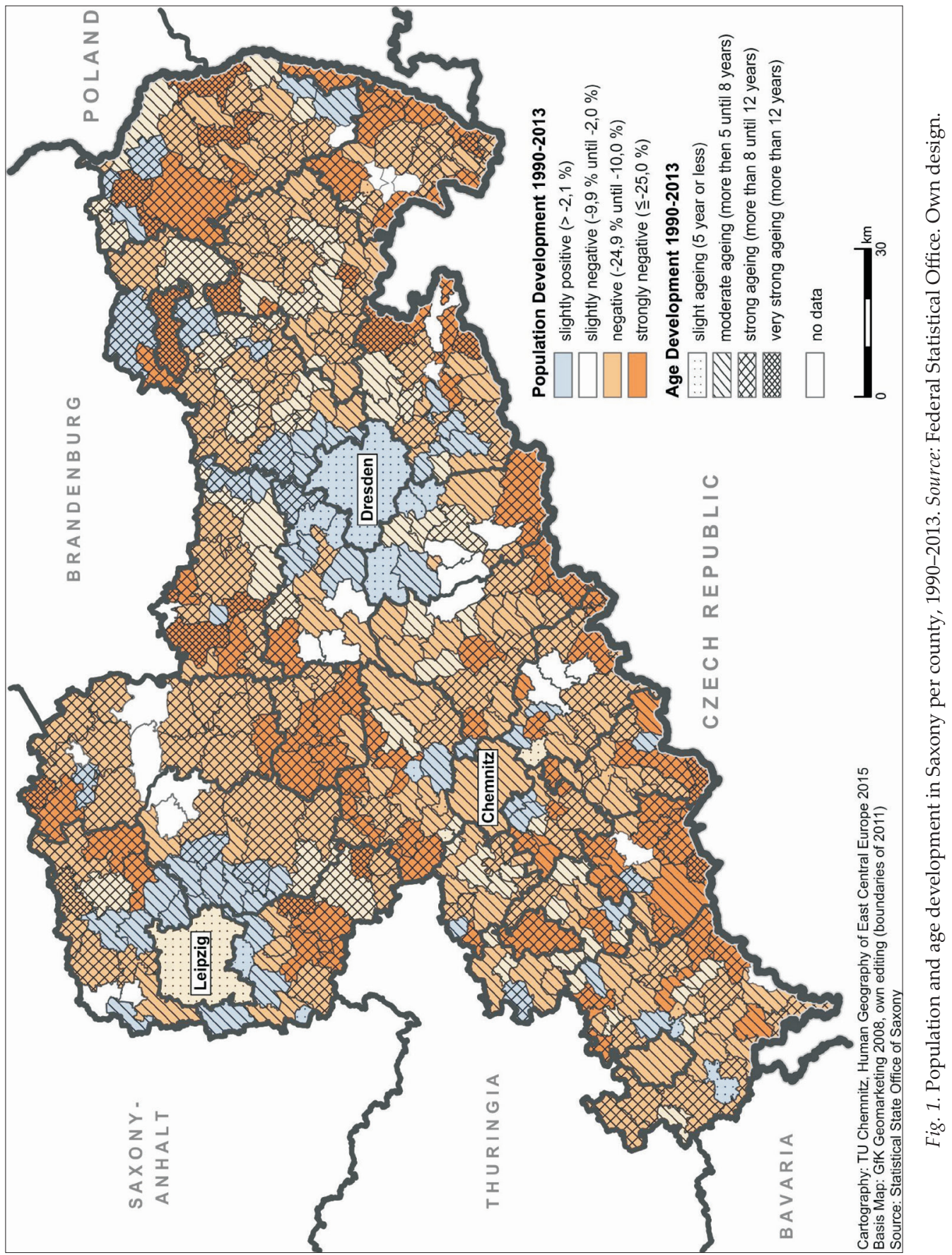


In the beginning of the 1990s the immigration dynamics to Germany changed drastically and, thus, also touched the new federal states which were reunited with the western part at October $3^{\text {rd }}$ 1990: There was a huge inflow of asylum seekers (ca. 1 million from 1991-1993) - especially refugees from the Balkan wars (ca. 290,000 from 1991-1993) -, resettlement migration of ethnic Germans from Eastern Europe (ca. 850,000 from 19901992, and around 2 million from 1990-1999) as well as arrivals of Jewish quota refugees from the former Soviet Union (28,462 in 1991-1992) (Haug, S. and Schimany, P. 2005; BAMF 2014). All those groups had in common that they could not settle at free choice, but they were distributed under the paradigm of burden sharing among and within the German federal states. This is also the case regarding newly arriving asylum seekers, of which the federal state of Saxony - according to the national distribution key "Königsteiner Schlüssel" - has to accommodate 5.1 per cent (BAMF 2016, 13).

A further group of international migrants residing in Saxony are European free movers. Their numbers increased significantly since the new EU member states gained full freedom of residence. Due to Saxony's location bordering Poland and the Czech Republic, there are significant immigration numbers from those two countries. But also the number of migrants from Southern European EU-member states has increased since those countries are facing financial and economic crises. Lastly, there is a considerable number of international students residing in Saxony on a temporary basis. Summing up those groups, the federal state of Saxony hosted around 164,000 foreigners in the end of 2015, which represented 4 per cent of its total population (Table 1).
Refugee reception, distribution and accommodation in Saxony

Since the changes of the Federal Law of Asylum in 1993, the number of incoming asylum seekers and asylum applications had been steadily decreasing and reached levels of ca. 20,000 in the beginning of the cs 2000s. Due to increasing conflicts in the Near East and the constant inflow of refugees over the Mediterranean in the 2000s, countries of arrival like Italy were facing severe reception and accommodation problems and refugees started to move onwards, for example to Germany. Since 2014, refugees from the West Balkans and those travelling over the Balkan route hes led to quickly increasing arrival numbers of asylum seekers in Germany. While in 2014, there were ca. 174,000 first time asylum applications in Germany, this number increased to about 442,000 in 2015 , but the arrival numbers prior to registration and asylum application were estimated around one million for the same year (BAMF 2016, 7). As the federal office for migration and refugees fell behind in the registration and application procedures, the number of asylum applications was still increasing in the years 2016 (ca. 722,000 first time applications) and 2017, even though the number of arriving asylum seekers dropped since the closure of the Balkan route in March 2016 (BAMF 2017a).

After crossing the German border, asylum seekers are registered by the federal police and then distributed over the federal states according to their shares of total population and economic situation (BAMF 2016, 13). The federal state of Saxony has to accommodate 5.1 per cent of all newly arriving asylum seekers, which made 6,030 persons in 2014, 27,180

Table 1. Main groups of foreigners in Saxony between 2013 and 2015

\begin{tabular}{|c|c|c|c|}
\hline Population groups & 2013 & 2014 & 2015 \\
\hline Total population & $4,046,385$ & $4,049,504$ & $4,084,851$ \\
\hline Foreign population, of which & 106,663 & 123,648 & 164,230 \\
\hline EU free movers & 37,147 & 43,561 & 50,182 \\
\hline asylum seekers & 5,663 & 11,163 & 32,201 \\
\hline international students & 13,610 & 15,472 & 16,611 \\
\hline
\end{tabular}

Source: Der Sächsische Ausländerbeauftragte 2015, 130; 2016, 152. 
in 2015 and 23,661 in 2016 (measured in terms of first asylum applications; see BAMF 2017b, 5). Among the federal states, refugees are again distributed over the counties according to population share. Figure 2 displays the distribution of asylum seekers in counties and cities of the federal state of Saxony in February 2015 and shows that practically every region is touched. However, the proportion of asylum seekers within the total population still is quite moderate, mostly varying between one and two percent.

Since 2013, counties and towns in Saxony agreed on a desegregation strategy, aiming to provide individual accommodations for about 50 per cent of all asylum seekers. After arriving from the federal first reception facility, asylum seekers usually spend a couple of weeks in a collective facility of the county or town. Then they are allocated to individual apartments, which are preferably offered to families with children, but also to groups of individuals. However, the implementation of this strategy varies considerably between counties and towns, which is (among other reasons) due to the differing availability of adequate housing facilities (Figure 3).

\section{Refugee reception and the challenge of diversity in rural regions of Saxony - methodology and findings}

\section{Research methodology}

Since the year 2015, the author has been carrying out fieldwork in rural municipalities in Saxony in order to explore commonalities and differences in the reception situation, the interactions between asylum seekers and local population and the public discourses evolving around the reception of asylum seekers. The research design consists of a mixed methods approach, containing expert interviews with politicians, administration professionals, social workers and teachers for migrants, focused interviews with migrants, as well as participant observation and the analysis of administrative bulletins, newspaper articles and social media blogs. The following elaborations display results from a first series of interviews (Table 2) concentrating on the management of reception and accommodation procedures, integration practices, personal experiences and underlying problems.

The experts were found in the counties "Meissen" and "Landkreis Leipzig", while other county officials refused to take part in the study, due to time constraints, but also because of the high level of public attention for the topic and possible negative consequences for their daily work. Interviews followed a common structure, using an interview guide which contained the main topics of interest, which were the genealogy of refugee reception, the constellation of actors in the field, specific challenges and problems and an assessment of local integration potentials. The interview guide ensured the comparative character of the interviews and at the same time left enough room for the interviewee to express additional issues. The interviews were taped, transcribed and analysed via thematic content analysis.

The main aim of the analysis was to find commonalities and divergences in the local practices and strategies of refugee reception

Table 2. Characterisation of interviewees

\begin{tabular}{l|c|c}
\hline \multicolumn{1}{c|}{ Type of interviewee and field of expertise } & Date of the interview & Code \\
\hline Mayor & 26.05 .2015 & \#E1 \\
Mayor & 28.05 .2015 & \#E3 \\
County representative, social affairs & 28.05 .2015 & \#E4 \\
Housing administration, social worker & 03.06 .2015 & $\# \mathrm{E} 5$ \\
German teacher for young asylum seekers & 08.02 .2016 & \#1 \\
Asylum seeker & 10.06 .2016 & \\
\hline
\end{tabular}

Source: Own data. 


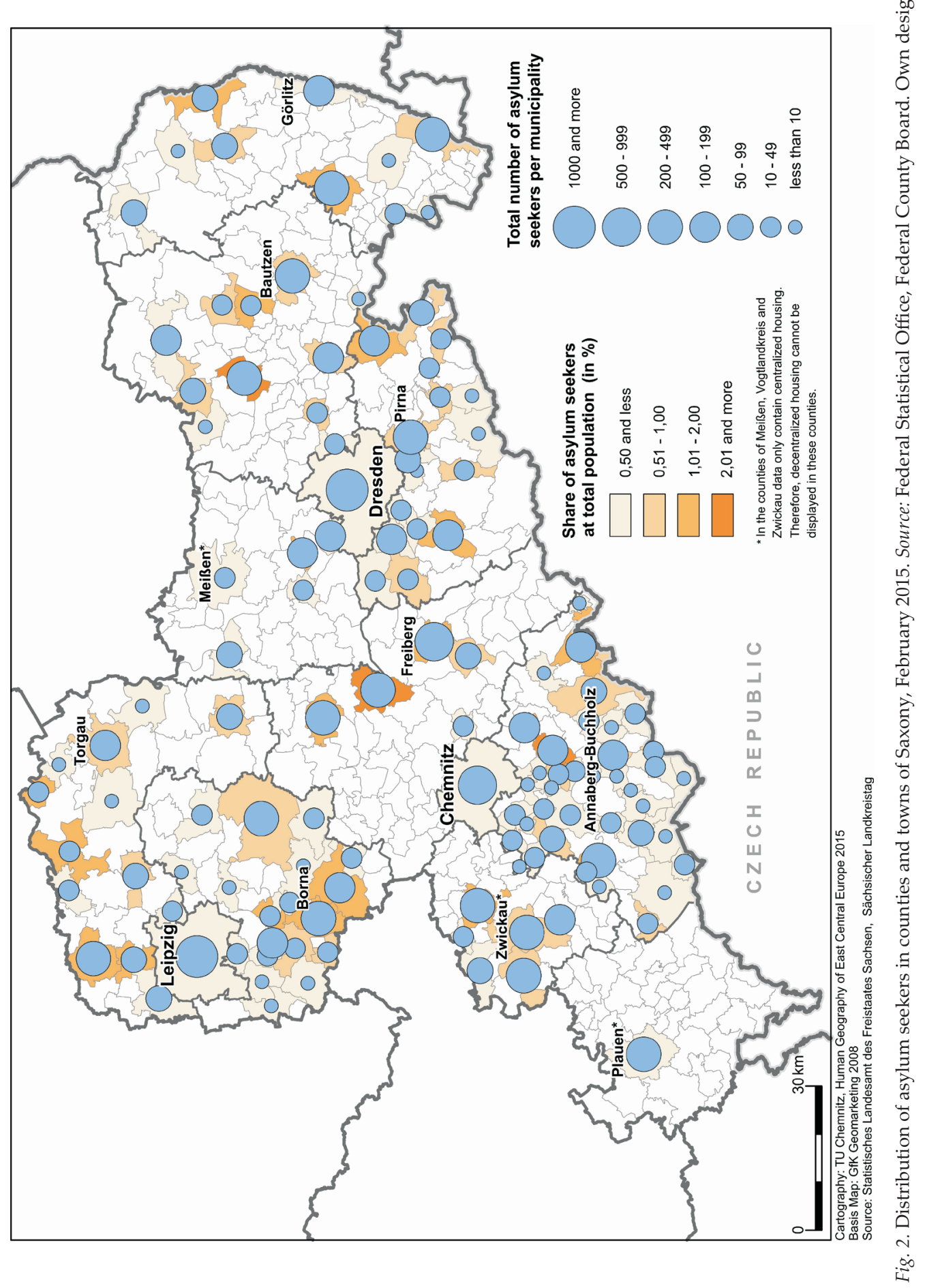




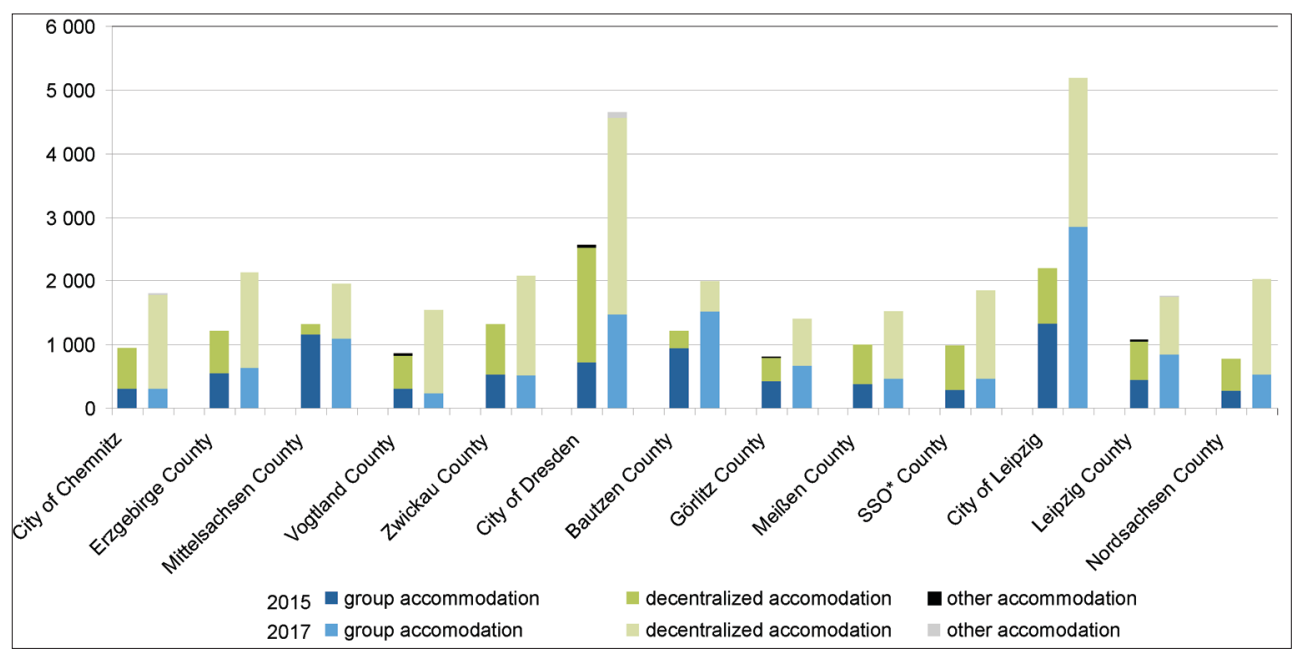

Fig. 3. Asylum seekers in Saxony per type of accommodation, February 2015, 2017. *Sächsische Schweiz Osterzgebirge. Source: Federal Statistical Office, Federal County Board. Own design.

and the development of local discourses. Special interest was given to the question, how the experts' perception of local discourses influenced their professional activities and decisions regarding the management of refugee reception. For further validation of the arguments, data from two interviews with a teacher and a young asylum seeker were integrated in this elaboration. They were drawn in the context of a study on integration of refugee youth into vocational schools in the county "Erzgebirgskreis."

\section{Diversity and xenophobia in discourse and practice}

Rural populations such as in the case study regions in rural Saxony appear to have little experience with diversity. Migration experiences mainly consist of the huge internal outflow, which - due to its selectivity - left behind local populations with high levels of ageing, unemployment and other social problems (Dornbusch, R. and Wolf, H.C. 1994; Glorius, B. 2010; CudnY, W. 2012). In

\footnotetext{
${ }^{4}$ All interviews were held in German and were later translated into English.
}

those local populations, outdated patterns of thought and behaviour from socialist times persisted to a large extend, such as the contradictory behaviour towards international migrants: During socialist times, the presence of labour migrants was justified with the obligation of international socialist solidarity with countries such as Poland, Vietnam and Cuba, while in everyday-life migrants from those countries were living segregated and under strict control of security police. Contacts between locals and foreigners were rare and not supported by the state, who suspected that migrants from more liberal socialist states such as Poland might bring counterrevolutionary ideas into the country. This brought forward manifold stereotypes and accusations, which were reflected by the daily press and, thus, legitimated xenophobic and racist stereotypes of the resident population. In relative absence of foreigners, racist stereotypes were never reflected and, thus, remain stable even in the higher strata of today's East German society (MüNCH, S. 2013).

This argumentation can be found in the expert interviews, as in the following quote from an interview with the mayor of a county town, who is explaining (and excusing) the negative reactions of some locals against refugees: 
"They rarely have experiences with foreigners. On holidays, yes, then I go to the bazaar, there is bustle, it's loud, there are exotic smells, but I definitely don't want to have this at home in front of my doorstep." (Mayor \#E2)

Also in other interviews there was a tendency to excuse or "naturalize" xenophobic behaviour of the local population, like in the following quote from a teacher of an integration class for young asylum seekers, who reflects her experiences doing fieldtrips with her students:

"I also do fieldtrips with larger groups even though we are being recognized in the bus and in the train and sometimes we annoy people. The students don't do any harm, but if I am showing up with a group, and there are ten coloured students who raise all attention, then you experience just the normal life here, so sometimes you are harrassed and shouted at." (Teacher \#E5)

Also the asylum seekers witness negative reactions of locals, starting with negative non-verbal and verbal reactions up to vandalism against their accommodation and personal attacks:

"Many people just approach me and ask 'What do you want here? Why don't you leave?' and you can do nothing about it. (...) They say, this is not my home, and that I receive money without doing anything for it, and I don't want to explain myself all the time." (Asylum Seeker \#M1).

After this interviewee's accommodation was attacked several times, he addressed the mayor of the town, who suggested to move to another town, where people might be less hostile.

Those xenophobic discourses and practices as described above are embedded into a discoursive frame that plays down daily racism, so that it appears as "normal" and justified behaviour. In this context, the attitudes and public gestures of local key persons such as mayors, school directors or priests play a crucial role for the development of local attitudes and practices. The passivity which was displayed by the interviewed experts in those municipalities hinders a reflection of xenophobic attitudes and even prepare the ground for harsh xenophobic and anti-islamic reactions and racist assaults.

Xenophobia without foreigners and the importance of first hand contact

Following J.W. BERRY's (2006) argumentation, continuous first-hand contact is crucial for the acculturation process. Asylum seekers who are located in large compounds have difficulties to achieve first hand contacts with locals, apart from contact with integration professionals or NGOs. Analysing the institutional strategies for the accommodation of asylum seekers in rural municipalities, the strategy of decentralized refugee housing is framed in a twofold way: Whereas on the one hand, the argumentation follows BERRY and stresses the greater ease to get into daily contact and, thus, create a higher level of acceptance - and of mutual support -, decentralization is also pursued to prevent the stigmatization of neighbourhoods or draw the attention of right wing radicals.

According to the author's observations and interviews, the actual experience of living side by side with a foreign family indeed stimulates contact, understanding and mutual help. Especially in the smaller towns with scarce or no social infrastructure, there are German neighbours who call in and try to solve administrative issues for the asylum seekers, as an interviewee (social worker \#E5) reports. According to her opinion, this behaviour is closely connected to the tradition of mutual help, especially in the remote villages, and the newcomers are not excluded from this tradition.

On the other hand, in the absence of foreigners, racist stereotypes are produced and reproduced on the basis of rumours spreading through printed and social media. This becomes evident in the following quote reflecting a town meeting prior to the allocation of asylum seekers and the attitudes that were displayed by the local population during the public discussion: 
"Sometimes I find it very difficult to understand where those fears come from, it's actually the fear of the unknown. Because if you get to ask more deeply, there has never been any contact with refugees. It is a fear of something which is completely unknown. For me, personally, this is always difficult to understand" (Social worker \#E4).

This quote indicates that the observed public reactions might not (only) be based on racist motives, but on the anticipation of changes in the local environment which might have negative consequences for the own way of living. Those fears develop on the basis of stereotypes about the cultural otherness of the newcomers, including assumptions on deviating ways of living that could disturb one's own lifestyle, for example because of noise, unusual smells or formerly unknown use of public spaces. During the public meetings, however, those individual stereotypes are collectively reinforced. Quite frequently, following the interviewees and participant observation results, town meetings in the context of asylum seeker allocations are infiltrated by right-wing activists, who use populist methods to raise public resistance and provoke aggressive and racist remarks. In the observed cases, public officials failed to develop a proactive and deescalating communication strategy which could support a rational discourse among local inhabitants. This is all the more problematic when one considers the discourse leading role of key persons in rural communities.

\section{The effects of relative deprivation}

The correlation between deprivation and extreme right-wing attitude has been repeatedly described and confirmed in empirical studies. The increase of extreme right-wing attitudes is contextualised with a perceived or actually experienced social decline - not only in postsocialist Germany, but also in neighbouring European countries (Heitmeyer, W. 2010; Küpper, B. and ZICK, A. 2010). The perception of relative deprivation is found to result in a destructive attitude against democratic principles and institutions and leads to the re- jection of social groups that are perceived as being different. Social groups suffering from relative deprivation frequently feel attracted by authoritarian, chauvinist or right-wing extremist ideas (HeItMeyer, W. 1997; ENDRIKAт, K. et al. 2002; SснміDT, M.G. et al. 2003). Indeed empirical studies find differences between East and West Germans, with the East Germans more strongly tending towards chauvinist, racist and social-darwinist attitudes and propagating authoritarian regimes (Decker, O. et al. 2014, 35) (Table 3).

A survey on the participants of the xenophobic "Pegida" movement found even higher right wing extremist, chauvinist and xenophobic attitudes than in the total of the East German population (DAPHY, P. et al. 2015, 29). The study also found very high levels of distrust against all sorts of public institutions, political actors and the media (ibid. 27).

During the expert interviews, political and administrative actors expressed their awareness of the fact that public distrust can threaten their own legitimacy as public representatives. Consequently, they developed a strategy to cope with public distrust and tried to create as much transparency as possible prior to the refugee assignment. As the distribution of refugees affects different levels of governance and as the registration and application procedure dropped behind the inflow of refugees during the year 2015, the municipalities - as the last link in the administrative chain - were frequently left mal-informed on details of those refugees that were allocated to their municipality. Neither were they informed about exact numbers, nor about special needs, or about cultural, ethnic or religious characteristics.

As the people in charge knew how important transparency is for a trustful relationship between local populations and legislation, they organized information meetings prior to the arrival of refugees. However, this was not effective as they had no details to tell, as this mayor explains:

\footnotetext{
5 „Pegida“ stands for „Patriotische Europäer gegen die Islamisierung des Abendlandes" / "Patriotic Europeans against the islamisation of the western world".
} 
Table 3. Right wing and extremist attitudes in East and West Germany in 2014 in per cent

\begin{tabular}{|c|c|c|c|}
\hline Attitudes & Total & East* & West $^{* *}$ \\
\hline Advocacy of dictatorships & 3.6 & 5.6 & 3.1 \\
\hline Chauvinism & 13.6 & 15.8 & 13.0 \\
\hline Xenophobia & 18.1 & 22.4 & 17.0 \\
\hline Antisemitism & 5.1 & 4.5 & 5.2 \\
\hline Social darwinism & 2.9 & 4.6 & 2.5 \\
\hline Derogation of national socialism & 2.2 & 1.2 & 2.5 \\
\hline
\end{tabular}

${ }^{*} \mathrm{~N}=503,{ }^{* *} \mathrm{~N}=1,929$. Source: DeCKer, O. et al. 2014.

"I have no problem to step in front of the masses and tell them 'that's how it is, that's we have to go through', but when I am asked 'Who is actually coming?', and I say 'I don't know!' - you can say that once, but at the second or third occasion, you lose your credibility" (Mayor \#E1).

A further aspect covered by relative deprivation theory is the fact that the newly arriving refugees enlarge the population entitled for social benefits. This results in distribution conflicts of social goods of limited availability, like social housing, and, thus, scales up social envy. The interviewees in the present case study contextualize this fact with the general social problematics in their county, which resulted from economic transformation and public cutbacks. The new conflict on social benefits for refugees is just one more example of social deprivation in the eyes of those social groups who perceive themselves as losers of the transformation:

“That's why I say, we don't have problems because of the asylum seekers, but because of the general social problematics." (County representative \#E3).

Even though only parts of the local populations are actually deprived, the perception of being disadvantaged against a group of newcomers and the question if the needs of those newcomers are legitimate or not prepares the ground for hostile discourses and concomitant racist activities.

\section{Conclusion}

Summing up, this paper addressed the question of preparedness for the challenges of heterogeneity in regions and populations for- merly untouched by international migration. It deals with the case of refugee accommodation in the federal state of Saxony, which is largely characterized by remote regions that underwent a peripheralisation process during the last decades due to population losses. In a naïve sense, those regions have plenty of space for newly arriving migrants. But are they ready to respond to the challenge of diversity? The paper drew on theories from social psychology to explain intergroup behaviour, like acculturation theory, social identity theory and relative deprivation approach. Also, it gave an overview on existing (but scarce) empirical evidence on migration and integration in rural regions. Many of the findings from those studies and of the hypotheses drawn from the theoretical elaborations could be supported by the presented results.

Relative deprivation theory helped to understand the development of right wing extremist attitudes, combined with a decreasing legitimacy of public institutions. Social groups fighting against deprivation were confirmed in their distrust and their "otherness" by the experience of mal-information on arriving refugees and by perceiving refugees as social group inferior to them, albeit competing for social support. Low intercultural competence and xenophobic reactions could be explained with the historical context of a homogeneous society where heterogeneity was officially denied. Also missing first hand contact serves as explanation for existing fears and xenophobic reactions, and the historical context of nation building and national belonging might reinforce the concept of ethnic homogeneity and, thus, oppose the settlement of strangers. As earlier findings 
on rural regions suggested, the crucial role of key persons in shaping local discourses on integration were also found in this case study. Unfortunately, in the discussed local examples, the passive role of key persons supported the spreading of rumours and enforcement of xenophobic stereotypes and offered right-wing activists an entry gate for taking over local discourses. In the relevant cases, right-wing activists not only acted openly on town meetings, but also had massive influence in local networks which formed in social media.

In generalized terms, those findings may be relevant also for other parts of post-socialist Europe, which are simultaneously struggling to cope with the effects of economic transformation and with the adaptation towards a more civic nationhood model in the course of EU integration and societal modernization. In this context, the recent arrival of asylum seekers appears to have a catalyst role, by highlighting existing societal conflicts that so far were not openly addressed. Pending tasks concerning the integration of refugees could bring forward necessary debates about social cohesion and might furthermore fuel processes of institutional adaptation and social innovation. However, in order to maintain social peace, local actors in rural regions must be empowered to take over a leading role in local discourses, actively support civic engagement and fight the effects of destructive discourses.

\section{REFERENCES}

BAde, K. and Oltmer, J. 2004. Migration, Ausländerbeschäftigung und Asylpolitik in der DDR 19491989/90. Available at http://www.bpb.de/gesellschaft/migration/dossier-migration /56368/ migrationspolitik-in-der-ddr?p=all (Retrieved 15.12.2015).

Berry, J.W. 2006. Context of acculturation. In The Cambridge Handbook of Acculturation Psychology. Eds.: SAm, D.L. and Berry, J.W., Cambridge, Cambridge University Press, 27-42.

Bertelsmann Foundation 2015. Willkommenskultur in Deutschland. Entwicklungen und Herausforderungen. Ergebnisse einer repräsentativen Bevölkerungsumfrage in Deutschland. Gütersloh, Bertelsmann Verlag.
Billiet, J., Maddens, B. and Beerten, R. 2003. National identity and attitude toward foreigners in a multinational state: a replication. Political Psychology 24. 241-257.

Bundesamt für Migration und Flüchtlinge (BAMF) 2014. Migrationsbericht des Bundesamtes für Migration und Flüchtlinge im Auftrag der Bundesregierung. Migrationsbericht 2012. Nürnberg, BAMF.

Bundesamt für Migration und Flüchtlinge (BAMF) 2016. Das Bundesamt in Zahlen 2015. Nürnberg. BAMF.

Bundesamt für Migration und Flüchtlinge (BAMF) 2017a. Aktuelle Zahlen zu Asyl. Ausgabe Februar 2017. Nürnberg, BAMF.

Bundesamt für Migration und Flüchtlinge (BAMF) 2017b. Asylgeschäftsstatistik für den Monat Dezember 2016. Nürnberg, BAMF.

Ceobanu, A.M. and Escandell, X. 2008. East is West? National feelings and anti-immigrant sentiment in Europe. Social Science Research 37. 1147-1170.

CudnY, W. 2012. Socio-economic transformation of small towns in East Germany after 1990 - Colditz case study. Bulletin of Geography. Socio-economic Series 17. 33-43.

Daphy, P., Kocyba, P., Neuber, M., Roose, J., Rucht, D., School, F., Sommer, M., Stuppert, T.W. and ZaJAK, S. 2015. Protestforschung am Limit. Eine soziologische Annäherung an Pegida. ipb working papers. Berlin, WZB.

Decker, O., KIEsS, J. and BräHLER, E. 2014. Die stabilisierte Mitte. Rechtsextreme Einstellung in Deutschland 2014. Leipzig, Universität Leipzig.

Der Sächsische Ausländerbeauftragte 2015. Jahresbericht 2014. Sächsischer Landtag. 5. Legislatur-periode. Bautzen, Lausitzer Druckhaus GmbH.

Der Sächsische Ausländerbeauftragte 2016. Jahresbericht 2015. Sächsischer Landtag. 6. Legislatur-periode. Dresden, Neue Druckhaus Dresden GmbH.

Dornbusch, R. and Wolf, H.C. 1994. East German Economic Restructuring. In The Transition in Eastern Europe, Volume I. Eds.: Blanchard, P.J., Froot, K.W. and SACHS, J.D. Chicago, University of Chicago Press, 155-190.

Endrikat, K., Schäfer, D., Mansel, J. and Heitmeyer, W. 2002. Soziale Desintegration. Die riskanten Folgen negativer Anerkennungsbilanzen. In Deutsche Zustände. Ed.: Heitmeyer, W., Frankfurt/Main, Suhrkamp, 37-58.

European Commission 2015. Standard Eurobarometer 83, Spring 2015. Public opinion in the European Union. Report. Brussels, EU.

Glorius, B. 2010. Go West. Internal migration in Germany after reunification. Revue Belge de Géographie 3. 281-292.

Glorius, B. 2015. Ärzte für Sachsen. Fachkräftezuwanderung als Lösungsansatz für demographische Probleme? Geographische Rundschau 9. 26-33.

Gruber, M. 2013. Integration im ländlichen Raum. Ein Praxishandbuch. Innsbruck, Studienverlag. 
Haug, S. and Schimany, P. 2005. Jüdische Zuwanderer in Deutschland. Ein Überblick über den Stand der Forschung. Working Paper 3. Nürnberg, BAMF.

Heitmeyer, W. 2010. Krisen - Gesellschaftliche Auswirkungen, individuelle Verarbeitung und Folgen für die Gruppenbezogene Menschenfeindlichkeit. In Deutsche Zustände, Folge 8. Ed.: Heitmeyer, W., Frankfurt/Main, Suhrkamp Verlag, $13-48$.

Heitmeyer, W. ed. 1997. Was treibt die Gesellschaft auseinander? Bundesrepublik Deutschland: Auf dem Weg von der Konsens- zur Konfliktgesellschaft. Frankfurt/ Main, Suhrkamp Verlag.

Hilsberg, S. 2015. „Herrliche Tage waren das!“. In Friedliche Revolution und Demokratie. Perspektiven nach 25 Jahren. Eds.: Jesse, E. and Schubert, T., Berlin, Christoph Links Verlag GmbH, 103-118.

HJerm, M. 1998. National identities, national pride and xenophobia: a comparison of four Western countries. Acta Sociologica 41. (4): 335-347.

HJerm, M. 2003. National sentiments in Eastern and Western Europe. Nationalities Papers 31. 413-429.

Hoffmeyer-ZlotniK, J. 2000. Der Einfluss der Region auf Einstellungen zu Ausländern. In Deutsche und Ausländer: Freunde, Fremde oder Feinde? Empirische Befunde und theoretische Erklärungen. Eds.: Alba, R., Schmidt, M.G. and WAsmer, M., Opladen, VS Verlag für Sozialwissenschaften, 195-228.

JANSEN, F. 2016. In NRW und Sachsen gab es die meisten Angriffe auf Flüchtlingsheime. Tagesspiegel 12.02.2016, available at http://www.tagesspiegel. de/politik/auflistung-der-regierung-in-nrw-undsachsen-gab-es-die-meisten-angriffe-auf-fluechtlingsheime/12955304 .html (Retrieved 31.03.2017).

KüPper, B. and ZICK, A. 2010. Macht Armut menschenfeindlich? Zusammenhänge in acht europäischen Ländern. In Deutsche Zustände, Folge 9. Ed.: Heitmeyer, W., Frankfurt/ Main, Suhrkamp Verlag, 84-105.

Laschewski, L. 2009. The Formation and Destruction of Social Capital - Lessons from East German Rural Restructuring. Eastern European Countryside 15. 91-110.

Leibert, T. and Golinski, S. 2016. Peripheralisation: The Missing Link in Dealing with Demographic Change? Comparative Population Studies 41. (3-4): DOI: 10.12765/CPoS-2017-02en.

Miкsch, J. and Schwier, A. 2000. Fremde auf dem Lande. Frankfurt/Main, Otto Lembeck Verlag.

MüNCH, S. 2013. Rahmenbedingungen von Zuwanderung und interkulturellem Zusammenleben in den ostdeutschen Bundesländern eine Bestandsaufnahme. Raumforschung und Raumordnung 71. (3): 261-271.
Nadler, R., Kriszan, M., Nienaber, B. and Frys, W. 2010. Zuwanderung internationaler Migranten in schrumpfende ländliche Regionen. Die Fallbeispiele Ostsachen und Saarland. Europa Regional 18. (2-3): 107-121.

PARK, R. and Burgess, E.W. 1921. Introduction to the Science of Sociology. Chicago, University of Chicago Press.

Pettigrew, T.F. 2001. Summing up: Relative deprivation as a key social psychological concept. In Relative Deprivation. Specification, Development, and Integration. Eds.: WALKER, I. and SMith, H.J., Cambridge, Cambridge University Press, 351-374.

PrIEs, L. 1997. Neue Migration im transnationalen Raum. In Transnationale Migration. Soziale Welt, Sonderband 12. Ed.: PriEs, L., Baden-Baden, Nomos Verlag, 15-44.

Redfield, R., Linton, R. and Herskovits, M.J. 1936. Memorandum for the study of acculturation. American Anthropologist 38. 149-152.

Roos, U.M. 2016. Migration und Integration in ländlichen Räumen am Beispiel der saarländischen Kreisstadt Merzig. Eine empirische Untersuchung unter besonderer Berücksichtigung der Erfahrungen und Sichtweisen von Personen mit Migrationshintergrund. Saarbrücken, O.V.

Schader-Stiftung ed. 2011. Integrationspotenziale in kleinen Städten und Landkreisen. Ergebnisse des Forschungs-Praxis-Projekts. Darmstadt, SchaderStiftung.

Schmidt, M.G., Maes, J. and Gollwitzer, M. 2003. Längsschnittliche Effekte relativer Deprivation und relativer Privilegierung auf Fremdenfeindlichkeit im wiedervereinigten Deutschland. In Sozialpsychologie politischer Prozesse. Beiträge des 18. Hamburger Symposions zur Methodologie der Sozialpsychologie. Ed.: Witte, E.H., Lengerich, Pabst, 58-84.

Sмгтн, A.D. 1991. National Identity. Reno, University of Nevada Press.

TAFT, R. 1957. A Psychological Model for the Study of Social Assimilation. Human Relations 10. 141-156.

TAjfel, H. and Turner, J.C. 1986. The social identity theory of intergroup behaviour. In Psychology of intergroup relations. Eds.: WORCHEL, L.S. and Austin, W.G., Chicago, Chicago University Press, 7-24.

WeLsCH, W. 1999. Transculturality. The puzzling form of cultures today. In Spaces of culture: City, nation, world. Eds.: FeAtherstone, M. and Lash, S., London, Sage Publications, 194-213.

White, G.W. 2000. Nationalism and Territory: Constructing Group Identity in Southeastern Europe. Lanham, MD, Rowman \& Littlefield. 